\title{
Lymph node metastasis and high serum CEA are important prognostic factors in hormone receptor positive and HER2 negative breast cancer
}

\author{
YOSHIMASA KOSAKA $^{1 *}$, NAOKO MINATANI ${ }^{1 *}$, YOKO TANAKA $^{1}$, AKIKO SHIDA $^{1}$, \\ MARIKO KIKUCHI $^{1}$, HIROSHI NISHIMIYA ${ }^{1}$, MINA WARAYA ${ }^{1}$, HIROSHI KATOH ${ }^{1}$, TAKEO SATO ${ }^{2}$, \\ NORIHIKO SENGOKU ${ }^{1}$, HIROKAZU TANINO ${ }^{3}$, KEISHI YAMASHITA ${ }^{2}$ and MASAHIKO WATANABE ${ }^{2}$
}

Departments of ${ }^{1}$ Breast and Endocrine Surgery, and ${ }^{2}$ Surgery, School of Medicine, Kitasato University Hospital, Sagamihara, Kanagawa 252-0374; ${ }^{3}$ Department of Breast and Endocrine Surgery, Kobe University Hospital, Kobe, Hyogo 650-0017, Japan

Received February 8, 2018; Accepted September 12, 2018

DOI: $10.3892 / \mathrm{mco} .2018 .1716$

\begin{abstract}
In recent years, treatment options for breast cancer have increased, and prognosis has improved since the 1990s. The present study examined the prognosis for recurrence of breast cancer between 2006 and 2009, in comparison with the results of past treatments, and sought to guide future treatment strategies by elucidating present prognostic factors. A total of 662 patients with breast cancer stage 0-III who underwent surgery at Kitasato University Hospital between January 2006 and March 2009 were included. Cases were classified into four subtypes, based on the presence or absence of hormone receptors and human epidermal growth factor receptor 2 (HER2). Factors associated with recurrence and prognosis were then examined. The 5-year recurrence-free survival (RFS) was 94.9\% and the 5-year disease-specific survival (DSS) was 98.4\%. Factors related to RFS were pathological lymph node $(\mathrm{pN})$ positive [hazard ratio $(\mathrm{HR})=2.85, \mathrm{P}=0.001$ ], clinical lymph node $(\mathrm{cN})$ positive $(\mathrm{HR}=2.28, \mathrm{P}<0.01)$, and hormone receptor negative $(\mathrm{HR}=1.83, \mathrm{P}<0.05)$. Factors associated with DSS were $\mathrm{cN}$ positive $(\mathrm{HR}=4.55, \mathrm{P}<0.01), \mathrm{pN}$ positive $(\mathrm{HR}=3.40, \mathrm{P}<0.05)$, higher preoperative serum carcinoembryonic antigen (CEA) $(\mathrm{HR}=3.04, \mathrm{P}<0.05)$, and hormone receptor negative $(\mathrm{HR}=2.32$, $\mathrm{P}<0.05)$. In the hormone receptor positive HER2 negative, $\mathrm{cN}$-positive/pN-positive breast cancer group, RFS and DSS were poorer compared with the other groups. In this group, preoperative high CEA level was a poor prognostic factor. The prognosis for hormone receptor positive HER2-negative breast
\end{abstract}

Correspondence to: Dr Yoshimasa Kosaka, Department of Breast and Endocrine Surgery, School of Medicine, Kitasato University Hospital, 1-15-1 Kitasato, Minami-ku, Sagamihara, Kanagawa 252-0374, Japan

E-mail: y-kosaka@med.kitasato-u.ac.jp

*Contributed equally

Key words: breast cancer, lymph node metastasis, CEA, prognosis, Hormone receptor positive cancer has improved significantly since the 1990s. On the other hand, the prognosis for $\mathrm{cN}$-positive/pN-positive breast cancer was poor. Pre-treatment serum CEA positive cases exhibited a particularly poor prognosis.

\section{Introduction}

Breast cancer is the most frequently diagnosed cancer and the leading cause of cancer death in women worldwide, accounting for $23 \%$ (1.4 million) of the total new cancer cases and $14 \%$ $(458,400)$ of the total cancer deaths in $2008(1,2)$.

Breast cancer is a heterogeneous disease and has distinct morphological features and tumor subtypes (3-6). Breast cancer is classified into 4 subtypes: Luminal A (hormone receptor positive, HER 2 negative), luminal B (hormone receptor positive, HER2 positive), HER2-enriched (hormone receptor negative, HER2 positive), and triple negative (hormone receptor negative, HER 2 negative) by microarray and hierarchical clustering analysis (7-11). It is now classified into 5 subtypes using Ki-67 expression. This classification has been used to formulate guidelines for breast cancer therapy. It was used to determine systemic adjuvant therapies by subtype and risk categories in 2007 per the St. Gallen consensus meeting (12). The 11th St. Gallen (Switzerland) expert consensus meeting on the primary treatment of early breast cancer in March 2009 maintained an emphasis on targeting adjuvant systemic therapies to subgroups as defined by these predictive markers $(13,14)$.

We followed these guidelines and based our breast cancer therapy on expression of hormone receptors and HER2. Little is known about the prognosis of Japanese breast cancer patients treated according to subtype. There are no articles that described long-term prognosis and compared more recent outcomes with those of the 1990s. In this study, we examined prognosis of Japanese breast cancer patients from the 2000s, during which time we followed guidelines for therapy.

\section{Patients and methods}

A total of 662 patients with stage 0-III breast cancer underwent surgical resection in the Kitasato University Hospital 
between January 2006 and March 2009. We classified them into 4 subtypes: Hormone receptor positive/HER2 negative, hormone receptor positive/HER2 positive, hormone receptor negative/HER2 positive, and hormone receptor negative/HER2 negative known as triple negative. Systemic therapy was consistent with recommendations for each of the biological subtypes. Characteristics of the 662 patients are shown in Table I. Median follow-up period was 77 (2-109) months. TNM classification was used based on the 7th edition of the Union for International Cancer Control (UICC). Clinical lymph node metastasis was considered more than $10 \mathrm{~mm}$ minor axis based on computed tomography. The patients with neoadjuvant chemotherapy (NAC) were also classified to pTNM. The positive cut-off value of serum CEA was higher than $5 \mathrm{ng} / \mathrm{ml}$.

We extracted 87 cases with hormone receptor positive/HER 2 negative and $\mathrm{cN}$ positive/pN positive between April, 2009 and December, 2014 as the validation group. Median follow-up was 51 (5-96) months. The present study was approved by the Ethics Committee of Kitasato University.

Statistical analysis. Recurrence free survival (RFS) and disease specific survival (DSS) were analysed based on clinicopathologic characteristics. RFS and DSS were calculated using the Kaplan-Meier method, and survival differences were assessed using a log-rank test. Variables suggested to be prognostic factors on univariate analysis were subjected to multivariate analysis using a Cox proportional-hazards model. The P-value $<0.05$ was considered to indicate statistical significance. All statistical analyses were conducted with SAS software package (JMP Pro11, SAS Institute, Cary, NC, USA).

\section{Results}

Univariate analysis for RFS and DSS. 5-year RFS of surgically treated breast cancer was $94.9 \%$. Univariate prognostic factors for recurrence were serum value of $C E A \geqq 5.0 \mathrm{ng} / \mathrm{ml}$ (CEA positive) before cancer therapy $(\mathrm{P}<0.05)$, cT2-4 $(\mathrm{P}<0.001), \mathrm{cN}$ positive $(\mathrm{P}<0.0001)$, NAC $(\mathrm{P}<0.0001)$, mastectomy $(\mathrm{P}<0.001)$, hormone receptor negative $(\mathrm{P}<0.001)$, pT2-4 $(\mathrm{P}<0.01)$, and pN positive $(\mathrm{P}<0.0001)$ (Table II). 5-year DSS was $98.4 \%$. Univariate prognostic factors for DSS were serum value of CEA positive $(\mathrm{P}<0.01)$, cT2-4 $(\mathrm{P}<0.001), \mathrm{cN}$ positive $(\mathrm{P}<0.0001)$, hormone receptor negative $(\mathrm{P}<0.01)$, pT2-4 $(\mathrm{P}=0.01)$, and $\mathrm{pN}$ positive $(\mathrm{P}<0.0001)$ (Table III).

Multivariate analysis for RFS and DSS. Among the 662 patients, multivariate Cox proportional hazards model identified $\mathrm{pN}$ positive (hazards ratio $(\mathrm{HR})=2.85, \mathrm{P}=0.001$ ), $\mathrm{cN}$ positive $(\mathrm{HR}=2.28, \mathrm{P}<0.01)$, and hormone receptor negative $(\mathrm{HR}=1.83, \mathrm{P}<0.05)$ as significant independent factors for recurrence (Table II). In the multivariate model for DSS, cN positive $(\mathrm{HR}=4.55, \mathrm{P}<0.01), \mathrm{pN}$ positive $(\mathrm{HR}=3.40, \mathrm{P}<0.05)$, serum value of CEA positive $(\mathrm{HR}=3.04, \mathrm{P}<0.05)$ and hormone receptor negative $(\mathrm{HR} 2.32, \mathrm{P}<0.05)$ were identified as independent prognostic factors (Table III).

Kaplan-Meier curve of RFS and DSS by independent prognostic factors based on multivariate analysis. $\mathrm{cN}$ status was significantly different in recurrent cases (RFS of $\mathrm{cN}$ positive and negative were 70 and $88 \%$ respectively, $\mathrm{P}<0.0001$ ). $\mathrm{pN}$ status was significantly different in recurrent cases (RFS of $\mathrm{pN}$ positive and negative were 68 and $92 \%$ respectively, $\mathrm{P}<0.0001)$. RFS of hormone receptor negative breast cancer was worse than that of the hormone receptor positive group (71 and $89 \%$ respectively, $\mathrm{P}<0.001$ ).

$\mathrm{cN}$ positive cases had significantly poorer prognoses than the $\mathrm{cN}$ negative group (83 and $99 \%$ respectively, $\mathrm{P}<0.0001$ ). DSS of hormone receptor negative breast cancers was $91 \%$, whereas DSS of hormone receptor positive breast cancer was $97 \%(\mathrm{P}<0.01)$. The $\mathrm{pN}$ positive group showed poorer prognoses than the $\mathrm{pN}$ negative group (89 and $98 \%$ respectively, $\mathrm{P}<0.0001)$. DSS of the serum CEA positive group was worse compared with that of the negative group (83 and $97 \%$ respectively, $\mathrm{P}=0.0001$ ).

Intersection of clinical and pathological lymph node metastasis. Fig. 1A shows differences in RFS and DSS based on the intersection of $\mathrm{cN}$ and $\mathrm{pN}$ factors. The RFS and DSS of the $\mathrm{cN}$ positive/pN positive group were 65 and $81 \%$, respectively. This group was significantly worse off than the other groups.

Fig. 1B shows the prognosis of hormone receptor positive/HER2 negative according to intersection of $\mathrm{cN}$ and $\mathrm{pN}$. The $\mathrm{cN}$ positive/pN positive group showed poorer prognoses than the other groups in hormone receptor positive/HER2 negative types (RFS P<0.0001/DSS P<0.0001). Lymph node metastasis was not associated with recurrence and was not a prognostic factor in the other subtype groups.

Kaplan-Meier curve of RFS and DSS by serum value of CEA before cancer therapy. In hormone receptor positive/HER2 negative breast cancers, RFS and DSS for the serum CEA positive group were significantly worse compared with the CEA negative group (RFS $\mathrm{P}<0.05$, DSS $\mathrm{P}<0.0001$ ) (Fig. 2A).

In the $\mathrm{cN}$ positive/pN positive group, the RFS of CEA positive cases was $52 \%$ and for CEA negative cases was $66 \%$ $(\mathrm{P}<0.05)$. The DSS of CEA positive cases was $43 \%$ and CEA negative cases was $90 \%(\mathrm{P}<0.001)$ (Fig. 2B).

The RFS of CEA positive cases was $50 \%$ and that of CEA negative cases was $84 \%(\mathrm{P}<0.05)$ in the validation group. There was no significant difference in DSS ( $\mathrm{P}=0.26)$ (Fig. 2C).

\section{Discussion}

For the present research, we clarified breast cancer treatment according to hormone receptor expression and HER2 expression. We reported treatment outcomes compared with 1995-1996 patients (15). According to results reported by Nishimiya et al (15), recurrence rates for breast cancer in $1995-1996$ was $31.2 \%$. Mortality rate was $24.5 \%$. These numbers were 10.4 and $4 \%$ respectively in recent years. For hormone receptor positive breast cancers, RFS and DSS were 68.42 and $83.05 \%$ respectively in the 1990 s. In the 2000 s, these numbers were 89 and $97 \%$. These numbers were 60.20 and $64.88 \%$ respectively for hormone receptor negative breast cancer. In the 2000s, these numbers were 71 and $91 \%$. For HER2 positive breast cancer, RFS and DSS were 61.17 and $63.16 \%$ in the 1990 s, and 83 and $94 \%$ in the 2000s respectively. For HER 2 negative breast cancers, these numbers were 67.40 and $81.26 \%$ and 85 and $96 \%$ respectively. Prognoses 
Table I. Clinicopathologic characteristics of the 662 patients.

\begin{tabular}{|c|c|c|c|c|c|}
\hline Factors & No. & $\%$ & Factors & No. & $\%$ \\
\hline Patient & 662 & 100.0 & $\mathrm{pN}$ & & \\
\hline Age (median) & $56(24-93)$ & & $\mathrm{pNO}$ & 451 & 68.1 \\
\hline Sex & & & $\mathrm{pN} 1$ & 138 & 20.8 \\
\hline Female & 657 & 99.3 & $\mathrm{pN} 2$ & 39 & 5.9 \\
\hline Male & 5 & 0.7 & $\mathrm{pN} 3$ & 22 & 3.3 \\
\hline Neo adjuvant therapy & & & Unknown & 12 & 1.8 \\
\hline Yes & 75 & 11.3 & pStage & & \\
\hline No & 587 & 88.7 & 0 & 116 & 17.5 \\
\hline $\mathrm{cT}^{\mathrm{a}}$ & & & $\mathrm{I}$ & 225 & 34.0 \\
\hline T0 & 104 & 15.7 & II & 227 & 34.3 \\
\hline $\mathrm{T} 1$ & 280 & 42.3 & III & 94 & 14.2 \\
\hline $\mathrm{T} 2$ & 215 & 32.5 & HR (IHC) & & \\
\hline $\mathrm{T} 3$ & 32 & 4.8 & Positive & 522 & 78.9 \\
\hline $\mathrm{T} 4$ & 31 & 4.7 & Negative & 140 & 21.1 \\
\hline $\mathrm{cN}$ & & & HER 2 (IHC and/or FISH) & & \\
\hline N0 & 530 & 80.1 & Positive & 67 & 10.2 \\
\hline N1 & 91 & 13.7 & Negative & 593 & 89.6 \\
\hline $\mathrm{N} 2$ & 32 & 4.8 & Unknown & 2 & 0.2 \\
\hline N3 & 9 & 1.4 & Subtype & & \\
\hline cStage & 104 & 155 & $\mathrm{HR}^{+} / \mathrm{HER}^{-}$ & 503 & 76.0 \\
\hline $\begin{array}{l}0 \\
\mathrm{I}\end{array}$ & $\begin{array}{l}104 \\
255\end{array}$ & $\begin{array}{l}15.5 \\
38.5\end{array}$ & $\mathrm{HR}^{+} / \mathrm{HER}^{+}$ & 19 & 2.9 \\
\hline $\begin{array}{l}1 \\
\text { II }\end{array}$ & $\begin{array}{l}255 \\
228\end{array}$ & $\begin{array}{l}38.5 \\
347\end{array}$ & $\mathrm{HR}^{-} / \mathrm{HER}^{+}{ }^{+}$ & 48 & 7.3 \\
\hline $\begin{array}{l}\text { II } \\
\text { III }\end{array}$ & $\begin{array}{c}220 \\
75\end{array}$ & $\begin{array}{l}34.1 \\
11.3\end{array}$ & $\mathrm{HR}^{-} / \mathrm{HER} 2^{-}$ & 92 & 13.8 \\
\hline Serum CEA & & & Postoperative adjuvant therapy & & \\
\hline $5>$ & 607 & 91.7 & Yes & 597 & 90.2 \\
\hline $5 \leq$ & 55 & 8.3 & No & 65 & 9.8 \\
\hline Surgical method & & & Recurrence & & \\
\hline Lumpectomy & 450 & 68.1 & Yes & 69 & 10.4 \\
\hline Mastectomy & 212 & 32.0 & No & 593 & 89.6 \\
\hline Lymphadenectomy & & & Succumbed & & \\
\hline Sentinel lymphnode biopsy & 360 & 54.4 & Yes & 26 & 4.0 \\
\hline Axillary lymphadenectomy & 267 & 40.3 & No & 636 & 96.0 \\
\hline Not performed & 35 & 5.3 & \multirow{4}{*}{\multicolumn{3}{|c|}{ 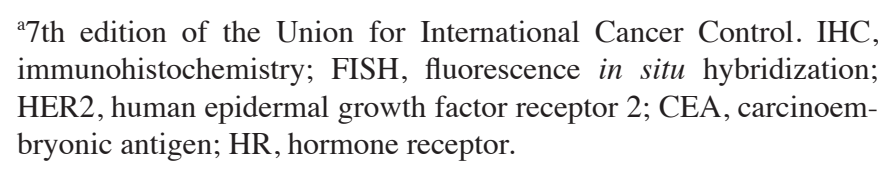 }} \\
\hline Pathological type & & & & & \\
\hline Ductal carcinoma in situ & 106 & 16.0 & & & \\
\hline Lobular carcinoma in situ & 2 & 0.3 & & & \\
\hline
\end{tabular}

500

54

Invasive lobular carcinoma

Nuclear grade

Grade 1

Grade 2

Grade 3

Unknown

pT
75.5

Table I. Continued

have improved in all subtypes. In the 2000s, it became clear 31.0 that prognosis was improving dramatically due to more 14.8 personalized medical treatment for breast cancer. All in all, 26.6 it is believed that the overall prognosis of breast cancer has 27.6 improved with diversification of hormonal therapies and chemotherapy along with the advent of molecular targeted therapeutic agents (16-23). Also in Japan, the prognosis for recurrent breast cancer has improved in the 2000s (24-26).

There is a limitation in this research. Ki-67 subtype was not analyzed yet. Ki-67 is a biomarker used for subtype classification in hormone receptor positive breast cancers. It has been drawing attention as a marker for possibility of recurrence $(14,15)$. Ki-67 cut-off values vary depending on 
Table II. Univariate and multivariate analysis for recurrence free survival (RFS).

\begin{tabular}{|c|c|c|c|c|c|c|}
\hline \multirow[b]{3}{*}{ Factors } & \multicolumn{6}{|c|}{ RFS } \\
\hline & \multicolumn{3}{|c|}{ Univariate analysis } & \multicolumn{3}{|c|}{ Multivariate analysis } \\
\hline & Patient number & RFS $(\%)$ & P-value & HR & $95 \% \mathrm{CI}$ & $\mathrm{P}$-value \\
\hline Age, years & & & 0.87 & & & \\
\hline$>56$ & 322 & 86 & & & & \\
\hline$<56$ & 340 & 80 & & & & \\
\hline Sex & & & 0.34 & & & \\
\hline Female & 657 & 84 & & & & \\
\hline Male & 5 & 100 & & & & \\
\hline CEA & & & $<0.05$ & & & NS \\
\hline $5>$ & 607 & 85 & & 1.79 & $0.86-3.37$ & \\
\hline $5 \leq$ & 55 & 81 & & & & \\
\hline $\mathrm{cT}$ & & & $<0.001$ & & & NS \\
\hline T0-1 & 384 & 90 & & 1.14 & $0.41-2.90$ & \\
\hline $\mathrm{T} 2-4$ & 278 & 77 & & & & \\
\hline $\mathrm{cN}$ & & & $<0.0001$ & & & $<0.01$ \\
\hline Negative & 530 & 88 & & 2.28 & $1.26-4.28$ & \\
\hline Positive & 132 & 70 & & & & \\
\hline cStage (7th UICC) & & & $<0.0001$ & & & \\
\hline 0 & 102 & 79 & & & & \\
\hline I & 255 & 91 & & & & \\
\hline II & 230 & 81 & & & & \\
\hline III & 75 & 71 & & & & \\
\hline Neo adjuvant therapy & & & $<0.0001$ & & & \\
\hline No & 587 & 86 & & & & \\
\hline Yes & 75 & 72 & & & & \\
\hline Surgical method & & & $<0.001$ & & & \\
\hline Lumpectomy & 450 & 91 & & & & \\
\hline Mastectomy & 212 & 73 & & & & \\
\hline Pathological type & & & 0.1 & & & \\
\hline DCIS & 106 & 74 & & & & \\
\hline LCIS & 2 & 100 & & & & \\
\hline IDC & 500 & 86 & & & & \\
\hline ILC & 54 & 45 & & & & \\
\hline Hormone receptor & & & $<0.001$ & & & $<0.05$ \\
\hline Negative & 140 & 71 & & 1.83 & $1.08-3.01$ & \\
\hline Positive & 522 & 89 & & & & \\
\hline HER 2 receptor & & & 0.08 & & & \\
\hline Positive & 67 & 83 & & & & \\
\hline Negative & 593 & 85 & & & & \\
\hline \multicolumn{7}{|l|}{ Subtype } \\
\hline $\mathrm{HR}^{+} / \mathrm{HER} 2^{-}$ & 503 & 89 & 0.01 & & & \\
\hline $\mathrm{HR}^{+} / \mathrm{HER} 2^{+}$ & 19 & 83 & & & & \\
\hline $\mathrm{HR}^{-} / \mathrm{HER} 2^{+}$ & 48 & 83 & & & & \\
\hline $\mathrm{HR}^{-} / \mathrm{HER} 2^{-}$ & 92 & 68 & & & & \\
\hline $\mathrm{pT}$ & & & $<0.01$ & & & NS \\
\hline T0-1 & 413 & 89 & & 1.02 & $0.42-2.79$ & \\
\hline $\mathrm{T} 2-4$ & 249 & 77 & & & & \\
\hline $\mathrm{pN}$ & & & $<0.0001$ & & & 0.001 \\
\hline Negative & 451 & 92 & & 2.85 & $1.52-5.30$ & \\
\hline Positive & 199 & 68 & & & & \\
\hline
\end{tabular}


Table II. Continued.

\begin{tabular}{|c|c|c|c|c|c|c|}
\hline \multirow[b]{3}{*}{ Factors } & \multicolumn{6}{|c|}{ RFS } \\
\hline & \multicolumn{3}{|c|}{ Univariate analysis } & \multicolumn{3}{|c|}{ Multivariate analysis } \\
\hline & Patient number & RFS $(\%)$ & $\mathrm{P}$-value & HR & $95 \% \mathrm{CI}$ & $\mathrm{P}$-value \\
\hline pStage (7th UICC) & & & $<0.0001$ & & & \\
\hline 0 & 116 & 84 & & & & \\
\hline I & 225 & 90 & & & & \\
\hline II & 227 & 92 & & & & \\
\hline III & 94 & 41 & & & & \\
\hline Adjuvant therapy & & & 0.2 & & & \\
\hline No & 65 & 94 & & & & \\
\hline Yes & 597 & 83 & & & & \\
\hline
\end{tabular}

HR, hazard ratio; CI, confidence interval; NS, not significant; DCIS, ductal carcinoma in situ; LCIS, lobular carcinoma in situ; IDC, invasive ductal carcinoma; ILC, invasive lobular carcinoma; HR, hormone recepto; HER2, human epidermal growth factor receptor 2; UICC, Union for International Cancer Contro; CEA, carcinoembryonic antigen.

A

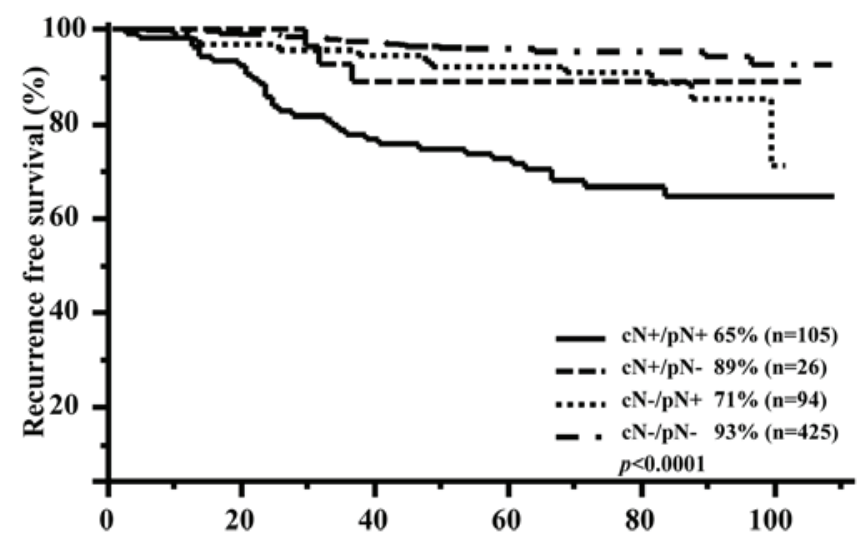

B

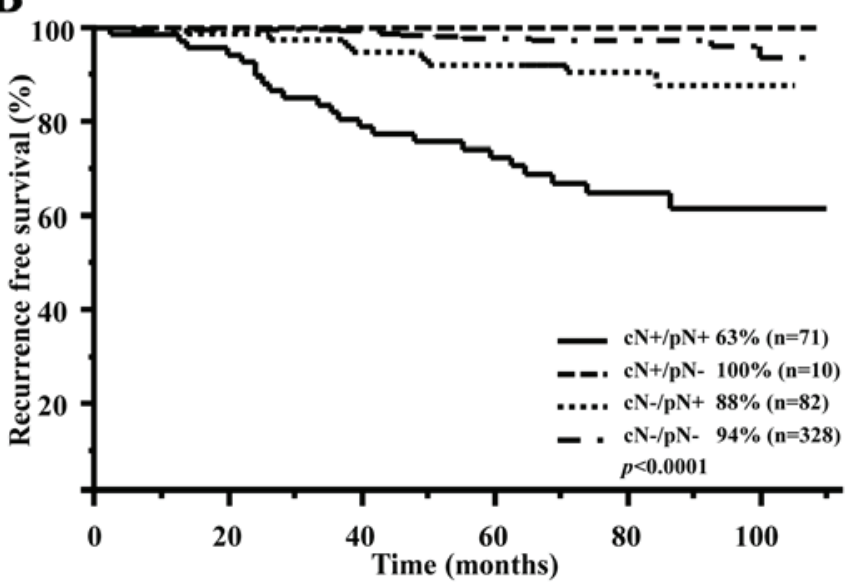

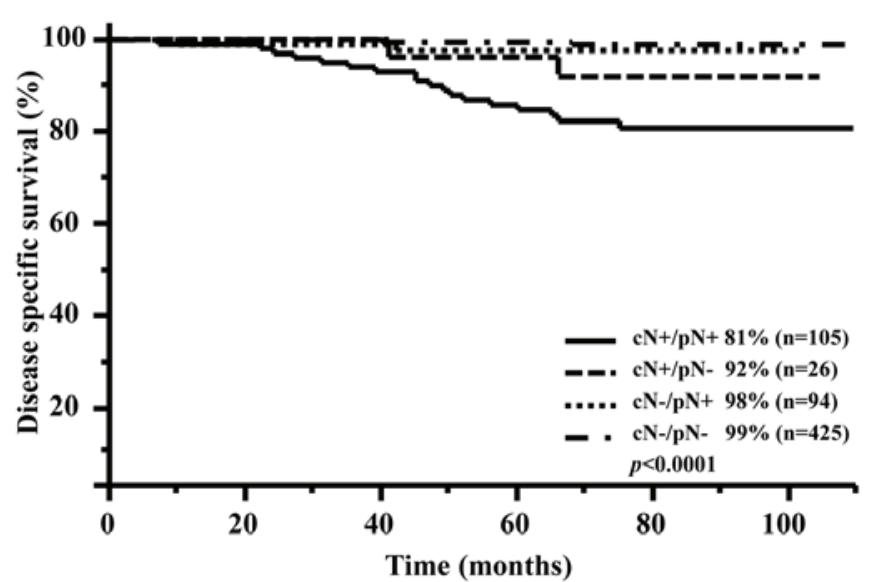

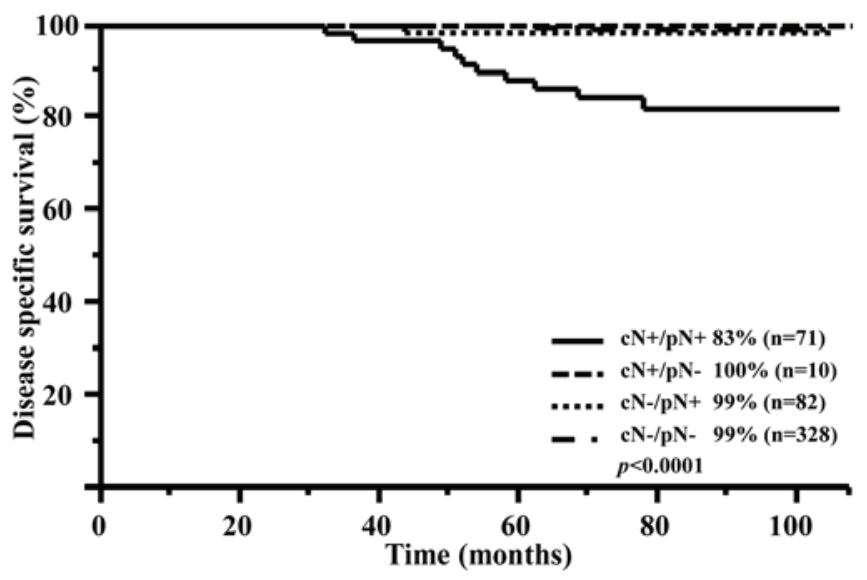

Figure 1. Kaplan-Meier curve of RFS and DSS by cN/pN status. (A) The RFS and DSS of cN positive and pN positive cases were significantly worse than those of the other groups. (B) $\mathrm{cN}$ positive/pN positive group showed poorer prognosis than the other groups in hormone receptor positive/HER 2 negative type.

lab factors including antibodies, time, staining methods, and methods for scoring. We believe that analysis according to Ki-67 will be necessary in the future.
Within the hormone receptor positive/HER2 negative group, the $\mathrm{cN}$ negative group had a good prognosis. In these cases, adjuvant hormone therapy was administered for 
Table III. Univariate and multivariate analysis for disease specific survival (DSS).

\begin{tabular}{|c|c|c|c|c|c|c|}
\hline \multirow[b]{3}{*}{ Factors } & \multicolumn{6}{|c|}{ DSS } \\
\hline & \multicolumn{3}{|c|}{ Univariate analysis } & \multicolumn{3}{|c|}{ Multivariate analysis } \\
\hline & Patient number & DSS (\%) & P-value & HR & $95 \% \mathrm{CI}$ & P-value \\
\hline Age, years & & & 0.66 & & & \\
\hline$>56$ & 322 & 95 & & & & \\
\hline$<56$ & 340 & 96 & & & & \\
\hline Sex & & & 0.57 & & & \\
\hline Female & 657 & 96 & & & & \\
\hline Male & 5 & 100 & & & & \\
\hline CEA & & & $<0.01$ & & & $<0.05$ \\
\hline $5>$ & 607 & 97 & & 3.04 & $1.17-7.03$ & \\
\hline $5 \leq$ & 55 & 82 & & & & \\
\hline $\mathrm{cT}$ & & & $<0.001$ & & & NS \\
\hline T0-1 & 384 & 98 & & 2.31 & $0.53-9.45$ & \\
\hline $\mathrm{T} 2-4$ & 278 & 92 & & & & \\
\hline $\mathrm{cN}$ & & & $<0.0001$ & & & $<0.01$ \\
\hline Negative & 530 & 99 & & 4.55 & $1.64-15.18$ & \\
\hline Positive & 132 & 83 & & & & \\
\hline cStage (7th UICC) & & & $<0.0001$ & & & \\
\hline 0 & 102 & 100 & & & & \\
\hline I & 255 & 99 & & & & \\
\hline II & 230 & 93 & & & & \\
\hline III & 75 & 87 & & & & \\
\hline Neo adjuvant therapy & & & $<0.001$ & & & \\
\hline No & 587 & 97 & & & & \\
\hline Yes & 75 & 86 & & & & \\
\hline Surgical method & & & 0.01 & & & \\
\hline Lumpectomy & 450 & 97 & & & & \\
\hline Mastectomy & 212 & 92 & & & & \\
\hline Pathological type & & & 0.33 & & & \\
\hline DCIS & 106 & 100 & & & & \\
\hline LCIS & 2 & 100 & & & & \\
\hline IDC & 500 & 95 & & & & \\
\hline ILC & 54 & 96 & & & & \\
\hline Hormone receptor & & & $<0.01$ & & & $<0.05$ \\
\hline Negative & 140 & 91 & & 2.32 & $1.02-5.17$ & \\
\hline Positive & 522 & 97 & & & & \\
\hline HER2 receptor & & & 0.37 & & & \\
\hline Positive & 67 & 94 & & & & \\
\hline Negative & 593 & 96 & & & & \\
\hline Subtype & & & $<0.05$ & & & \\
\hline HR+/HER2- & 503 & 97 & & & & \\
\hline $\mathrm{HR}^{+} / \mathrm{HER}^{2}{ }^{+}$ & 19 & 94 & & & & \\
\hline HR-/HER2 ${ }^{+}$ & 48 & 93 & & & & \\
\hline HR-/HER2- & 92 & 89 & & & & \\
\hline $\mathrm{pT}$ & & & 0.01 & & & NS \\
\hline T0-1 & 413 & 97 & & 1.51 & $0.38-5.01$ & \\
\hline $\mathrm{T} 2-4$ & 249 & 93 & & & & \\
\hline $\mathrm{pN}$ & & & $<0.0001$ & & & $<0.05$ \\
\hline Negative & 451 & 98 & & 3.40 & $1.08-11.17$ & \\
\hline Positive & 198 & 89 & & & & \\
\hline
\end{tabular}


Table III. Continued.

DSS

\begin{tabular}{|c|c|c|c|c|c|c|}
\hline & \\
\hline \multirow[b]{2}{*}{ Factors } & \multicolumn{3}{|c|}{ Univariate analysis } & \multicolumn{3}{|c|}{ Multivariate analysis } \\
\hline & Patient number & DSS (\%) & P-value & HR & $95 \% \mathrm{CI}$ & P-value \\
\hline pStage (7th UICC) & & & $<0.0001$ & & & \\
\hline 0 & 116 & 100 & & & & \\
\hline I & 225 & 97 & & & & \\
\hline II & 227 & 98 & & & & \\
\hline III & 94 & 82 & & & & \\
\hline Adjuvant therapy & & & 0.01 & & & \\
\hline No & 65 & 93 & & & & \\
\hline Yes & 597 & 96 & & & & \\
\hline
\end{tabular}

HR, hazard ratio; CI, confidence interval; NS, not significant; DCIS, ductal carcinoma in situ; LCIS, lobular carcinoma in situ; IDC, invasive ductal carcinoma; ILC, invasive lobular carcinoma; HR, hormone recepto; HER2, human epidermal growth factor receptor 2; UICC, Union for International Cancer Control; CEA, carcinoembryonic antigen.

\section{A Hormone receptor positive / HER2 negative group (Jan/2006-Mar/2009)}
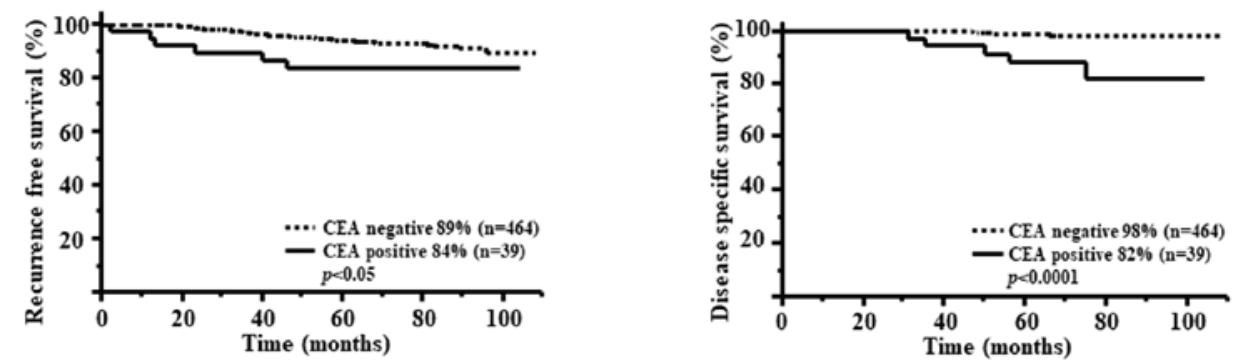

B cN positive / pN positive group: Training group (Jan/2006-Mar/2009)
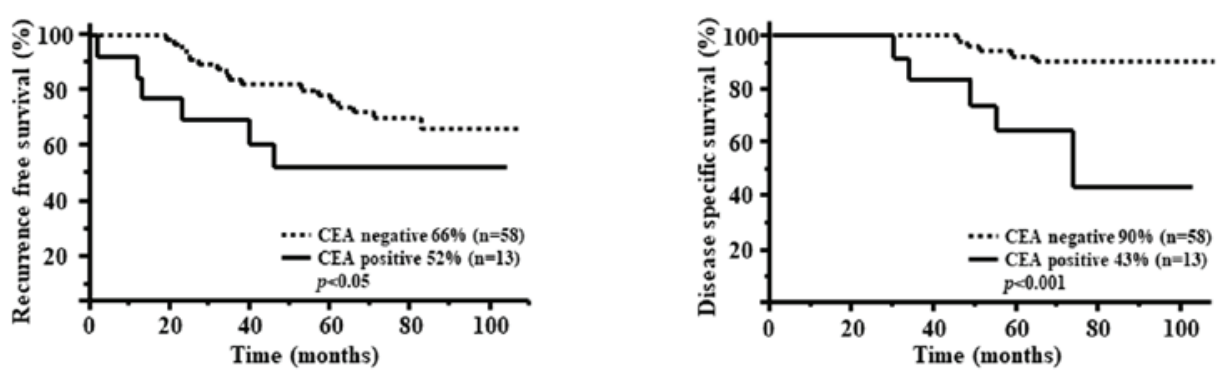

\section{$\mathrm{C}$ cN positive/ $\mathrm{pN}$ positive group: Validation group (Apr/2009-Dec/2014)}
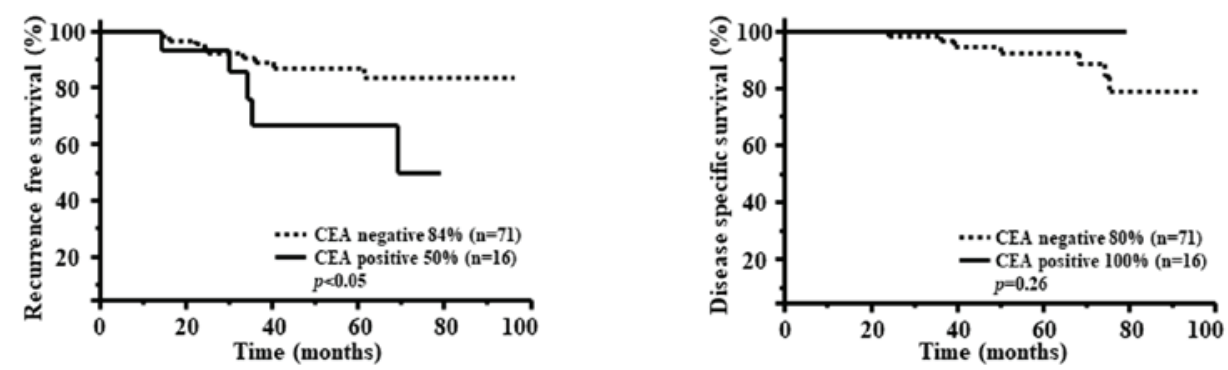

Figure 2. Kaplan-Meier curve of RFS and DSS by serum CEA values before cancer therapy. (A) The RFS and DSS of serum CEA values before cancer therapy positive group were significantly worse compared with the CEA negative group in hormone receptor positive/HER2 negative breast cancers. (B) In the cN positive/pN positive group, the RFS and DSS of CEA positive cases were worse than in the CEA negative group. (C) In the validation group, the RFS of CEA positive cases was worse than in the CEA negative group. 
5 years. Recently, studies such as ATLAS (27), attom (28), and MA17R (29) demonstrated the effectiveness of 10 years of hormone therapy. Nevertheless, there is no research determining the particular circumstances under which hormone therapy should be administered. In the present study, in multivariate analysis, factors relating to relapse included $\mathrm{cN}$, $\mathrm{pN}$, and the presence or absence of hormone receptor. Factors relating to prognosis were $\mathrm{cN}, \mathrm{pN}$, the presence or absence of hormone receptor, and pretreatment serum CEA values. The analysis of the Intersection of $\mathrm{cN}$ and $\mathrm{pN}$ was related to poor prognosis. Within the hormone receptor positive/HER2 negative group, the prognosis for the $\mathrm{cN}$ positive/pN positive group was particularly poor. Additionally, within the $\mathrm{cN}$ positive/pN positive group in the hormone receptor positive/HER2 negative group, there was a poor prognosis for those with high pretreatment CEA levels (Fig. 2B). Serum CEA is a tumor marker used for early detection and monitoring for recurrence of breast cancer, and for evaluating progress of therapy in patients with progressive, recurrent breast cancer in the clinical setting (30-35). Within the 87 cases of the validation group, there was a significant rate of recurrence in those with high serum CEA levels compared with those with low levels of CEA $(\mathrm{P}<0.05)$ (Fig. 2C). Nevertheless, future surveillance is necessary, since the follow-up period is insufficient. That is to say, in the $\mathrm{cN}$ positive/pN positive group, contemporary treatments were inadequate. We believe it is an urgent priority to develop stronger treatment algorithms or to develop new treatments that exceed the current standard. Taking these results into consideration, our facility plans to administer hormone therapy for 10 years to those patients with high serum CEA levels and $\mathrm{cN}$ positive/pN positive breast cancer. We will subsequently study the therapeutic effects and side effects such as osteoporosis of prolonged hormone therapy in this population.

Although the number of cases was small, the prognosis was the same in the $\mathrm{cN}$ positive/pN negative, and $\mathrm{cN}$ negative/pN negative groups. In these 10 cases, pretreatment imaging showed axillary lymph node enlargement of $10 \mathrm{~mm}$ or more. Eight out of the 10 cases received neoadjuvant chemotherapy, and these became $\mathrm{pN}$ negative (ypN0) after surgery. von Minckwitz et al (36) report a good prognosis for patients with ypNO induced by neoadjuvant chemotherapy. In the hormone receptor positive/HER2 negative/high Ki-67 expression group (Luminal B), the recurrence rate for pathological complete response (pCR) cases was low (36). In the NSABP B18 trial, good prognosis was reported for $\mathrm{pCR}$ cases $(37,38)$. There are additional reports of good prognosis in $\mathrm{pCR}$ cases with neoadjuvant chemotherapy compared with other cases $(39,40)$. That is to say, aggressive neoadjuvant chemotherapy should be performed for hormone receptor positive/HER 2 negative cases that are $\mathrm{cN}$ positive and with high levels of $\mathrm{Ki}-67$. It is considered possible to selectively induce good prognosis via neoadjuvant chemotherapy.

The $\mathrm{cN}$ positive/pN positive group had a poor overall prognosis. In hormone receptor positive/HER2 negative breast cancer, nodal metastasis was found to be a strong factor relating to the prognosis of recurrence. Furthermore, cases with elevated serum CEA had an especially poor prognosis; therefore the prolongation of hormone therapy is necessary.

\section{Acknowledgements}

Not applicable.

\section{Conflicts of interest}

None.

\section{Funding}

No funding was received.

\section{Availability of data and materials}

The datasets used and/or analyzed during the current study are available from the corresponding author on reasonable request.

\section{Authors' contributions}

YK and NM performed the statistical analysis and wrote the manuscript. YT, AS, MK, HN, MiW and HK participated in the interpretation of data and the critical review of the manuscript. TS, NS, HT, KY and MaW gave final approval of the version to be published, and made substantial contributions to the conception and design of the study. All authors read and approved the final manuscript.

\section{Ethics approval and consent to participate}

The present study was approved by the Ethics Committee of Kitasato University and written informed consents were obtained from the patients for publication of this study.

\section{Patient consent for publication}

Written informed consents were obtained from the patients for publication of this study.

\section{Competing interests}

The authors declare that they have no competing interests.

\section{References}

1. Jemal A, Bray F, Center MM, Ferlay J, Ward E and Forman D: Global cancer statistics. CA Cancer J Clin 61: 69-90, 2011.

2. Lam SW, Jimenez CR and Boven E: Breast cancer classification by proteomic technologies: Current state of knowledge. Cancer Treat Rev 40: 129-138, 2014.

3. Cleary AS, Leonard TL, Gestl SA and Gunther EJ: Tumour cell heterogeneity maintained by cooperating subclones in Wnt-driven mammary cancers. Nature 508: 113-117, 2014.

4. Geyer FC, Marchio C and Reis-Filho JS: The role of molecular analysis in breast cancer. Pathology 41: 77-88, 2009.

5. Weigelt B, Horlings HM, Kreike B, Hayes MM, Hauptmann M, Wessels LF, de Jong D, Van de Vijver MJ, Van't Veer LJ and bPeterse JL: Refinement of breast cancer classification by molecular characterization of histological special types. J Pathol 216: 141-150, 2008.

6. Yersal O and Barutca S: Biological subtypes of breast cancer: Prognostic and therapeutic implications. World J Clin Oncol 5: 412-424, 2014.

7. Parker JS, Mullins M, Cheang MC, Leung S, Voduc D, Vickery T, Davies S, Fauron C, He X, Hu Z, et al: Supervised risk predictor of breast cancer based on intrinsic subtypes. J Clin Oncol 27: 1160-1167, 2009. 
8. Perou CM, Sørlie T, Eisen MB, van de Rijn M, Jeffrey SS, Rees CA, Pollack JR, Ross DT, Johnsen H, Akslen LA, et al: Molecular portraits of human breast tumours. Nature 406: $747-752,2000$

9. Sorlie T, Tibshirani R, Parker J, Hastie T, Marron JS, Nobel A, Deng S, Johnsen H, Pesich R, Geisler S, et al: Repeated observation of breast tumor subtypes in independent gene expression data sets. Proc Natl Acad Sci USA 100: 8418-8423, 2003.

10. Fan C, Oh DS, Wessels L, Weigelt B, Nuyten DS, Nobel AB, van't Veer LJ and Perou CM: Concordance among gene-expression-based predictors for breast cancer. N Engl J Med 355: 560-569, 2006.

11. Sørlie T, Perou CM, Tibshirani R, Aas T, Geisler S, Johnsen H, Hastie T, Eisen MB, van de Rijn M, Jeffrey SS, et al: Gene expression patterns of breast carcinomas distinguish tumor subclasses with clinical implications. Proc Natl Acad Sci USA 98: 10869-10874, 2001

12. Goldhirsch A, Wood WC, Gelber RD, Coates AS, Thürlimann B and Senn HJ; 10th St. Gallen conference: Progress and promise: Highlights of the international expert consensus on the primary therapy of early breast cancer 2007. Ann Oncol 18: 1133-1144, 2007.

13. Goldhirsch A, Ingle JN, Gelber RD, Coates AS, Thürlimann B and Senn HJ; Panel members: Thresholds for therapies: Highlights of the St Gallen International expert consensus on the primary therapy of early breast cancer 2009. Ann Oncol 20 $1319-1329,2009$.

14. Goldhirsch A, Wood WC, Coates AS, Gelber RD, Thürlimann B and Senn HJ; Panel members: Strategies for subtypes-dealing with the diversity of breast cancer: Highlights of the St. Gallen International expert consensus on the primary therapy of early breast cancer 2011. Ann Oncol 22: 1736-1747, 2011.

15. Nishimiya H, Kosaka Y, Yamashita K, Minatani N, Kikuchi M, Ema A, Nakamura K, Waraya M, Sengoku N, Tanino H, et al: Prognostic significance of Ki-67 in chemotherapy-naive breast cancer patients with 10-year follow-up. Anticancer Res 34 259-268, 2014

16. Aebi S, Sun Z, Braun D, Price KN, Castiglione-Gertsch M, Rabaglio M, Gelber RD, Crivellari D, Lindtner J, Snyder R, et al: Differential efficacy of three cycles of CMF followed by tamoxifen in patients with ER-positive and ER-negative tumors: Long-term follow up on IBCSG Trial IX. Ann Oncol 22: 1981-1987, 2011.

17. Dafni U, Grimani I, Xyrafas A, Eleftheraki AG and Fountzilas G: Fifteen-year trends in metastatic breast cancer survival in Greece. Breast Cancer Res Treat 119: 621-631, 2010.

18. Dawood S, Broglio K, Gonzalez-Angulo AM, Buzdar AU, Hortobagyi GN and Giordano SH: Trends in survival over the past two decades among white and black patients with newly diagnosed stage IV breast cancer. J Clin Oncol 26: 4891-4898, 2008.

19. Gennari A, Conte P, Rosso R, Orlandini C and Bruzzi P: Survival of metastatic breast carcinoma patients over a 20 -year period: A retrospective analysis based on individual patient data from six consecutive studies. Cancer 104: 1742-1750, 2005.

20. Early Breast Cancer Trialists' Collaborative Group (EBCTCG) Effects of chemotherapy and hormonal therapy for early breast cancer on recurrence and 15-year survival: An overview of the randomised trials. Lancet 365: 1687-1717, 2005.

21. Arimidex, Tamoxifen, Alone or in Combination (ATAC) Trialists Group, Forbes JF, Cuzick J, Buzdar A, Howell A, Tobias JS and Baum M: Effect of anastrozole and tamoxifen as adjuvant treatment for early-stage breast cancer: 100-month analysis of the ATAC trial. Lancet Oncol 9: 45-53, 2008.

22. Smith I, Procter M, Gelber RD, Guillaume S, Feyereislova A, Dowsett M, Goldhirsch A, Untch M, Mariani G, Baselga J, et al: 2-year follow-up of trastuzumab after adjuvant chemotherapy in HER 2-positive breast cancer: A randomised controlled trial. Lancet 369: 29-36, 2007.

23. Piccart-Gebhart MJ, Procter M, Leyland-Jones B, Goldhirsch A Untch M, Smith I, Gianni L, Baselga J, Bell R, Jackisch C, et al: Trastuzumab after adjuvant chemotherapy in HER2-positive breast cancer. N Engl J Med 353: 1659-1672, 2005.

24. Shigematsu H, Kawaguchi H, Nakamura Y, Tanaka K, Shiotani S, Koga C, Nishimura S, Taguchi K, Nishiyama K and Ohno S: Significant survival improvement of patients with recurrent breast cancer in the periods 2001-2008 vs. 1992-2000. BMC Cancer 11: 118, 2011.
25. Kurebayashi J, Miyoshi Y, Ishikawa T, Saji S, Sugie T, Suzuki T, Takahashi S, Nozaki M, Yamashita H, Tokuda Y and Nakamura S: Clinicopathological characteristics of breast cancer and trends in the management of breast cancer patients in Japan: Based on the Breast Cancer Registry of the Japanese Breast Cancer Society between 2004 and 2011. Breast Cancer 22: 235-244, 2015.

26. Tamaki M, Kamio T, Kameoka S, Kojimahara N and Nishikawa T: The relevance of the intrinsic subtype to the clinicopathological features and biomarkers in Japanese breast cancer patients. World J Surg Oncol 11: 293, 2013.

27. Davies C, Pan H, Godwin J, Gray R, Arriagada R, Raina V, Abraham M, Medeiros Alencar VH, Badran A, Bonfill X, et al: Long-term effects of continuing adjuvant tamoxifen to 10 years versus stopping at 5 years after diagnosis of oestrogen receptor-positive breast cancer: ATLAS, a randomised trial. Lancet 381: 805-816, 2013.

28. Gray R, Davies C and Perry P: Tamoxifen for early breast cancer: Better late than never. Ann Oncol 11: 505-507, 2000.

29. Goss PE, Ingle JN, Pritchard KI, Robert NJ, Muss H, Gralow J, Gelmon K, Whelan T, Strasser-Weippl K, Rubin S, et al: Extending aromatase-inhibitor adjuvant therapy to 10 years. $\mathrm{N}$ Engl J Med 375: 209-219, 2016.

30. Uehara M, Kinoshita T, Hojo T, Akashi-Tanaka S, Iwamoto E and Fukutomi T: Long-term prognostic study of carcinoembryonic antigen (CEA) and carbohydrate antigen 15-3 (CA 15-3) in breast cancer. Int J Clin Oncol 13: 447-451, 2008.

31. Shao Y, Sun X, He Y, Liu C and Liu H: Elevated levels of serum tumor markers CEA and CA15-3 are prognostic parameters for different molecular subtypes of breast cancer. PLoS One 10: e0133830, 2015.

32. Lee JS, Park S, Park JM, Cho JH, Kim SI and Park BW: Elevated levels of preoperative CA 15-3 and CEA serum levels have independently poor prognostic significance in breast cancer. Ann Oncol 24: 1225-1231, 2013.

33. Pedersen AC, Sørensen PD, Jacobsen EH, Madsen JS and Brandslund I: Sensitivity of CA 15-3, CEA and serum HER2 in the early detection of recurrence of breast cancer. Clin Chem Lab Med 51: 1511-1519, 2013.

34. Park BW, Oh JW, Kim JH, Park SH, Kim KS, Kim JH and Lee KS: Preoperative CA 15-3 and CEA serum levels as predictor for breast cancer outcomes. Ann Oncol 19: 675-681, 2008.

35. Yang Y, Zhang H, Zhang M, Meng Q, Cai L and Zhang Q: Elevation of serum CEA and CA15-3 levels during antitumor therapy predicts poor therapeutic response in advanced breast cancer patients. Oncol Lett 14: 7549-7556, 2017.

36. von Minckwitz G, Untch M, Blohmer JU, Costa SD, Eidtmann H, Fasching PA, Gerber B, Eiermann W, Hilfrich J, Huober J, et al: Definition and impact of pathologic complete response on prognosis after neoadjuvant chemotherapy in various intrinsic breast cancer subtypes. J Clin Oncol 30: 1796-1804, 2012.

37. Wolmark N, Wang J, Mamounas E, Bryant J and Fisher B: Preoperative chemotherapy in patients with operable breast cancer: Nine-year results from National Surgical Adjuvant Breast and Bowel Project B-18. J Natl Cancer Inst Monogr: 96-102, 2001.

38. Rastogi P, Anderson SJ, Bear HD, Geyer CE, Kahlenberg MS, Robidoux A, Margolese RG, Hoehn JL, Vogel VG, Dakhil SR, et al: Preoperative chemotherapy: Updates of National surgical adjuvant breast and bowel project protocols B-18 and B-27. J Clin Oncol 26: 778-785, 2008.

39. Fisher B, Bryant J, Wolmark N, Mamounas E, Brown A, Fisher ER, Wickerham DL, Begovic M, DeCillis A, Robidoux A, et al: Effect of preoperative chemotherapy on the outcome of women with operable breast cancer. J Clin Oncol 16: 2672-2685, 1998.

40. Carey LA, Metzger R, Dees EC, Collichio F, Sartor CI, Ollila DW, Klauber-DeMore N, Halle J, Sawyer L, Moore DT and Graham ML: American Joint Committee on Cancer tumor-node-metastasis stage after neoadjuvant chemotherapy and breast cancer outcome. J Natl Cancer Inst 97: 1137-1142, 2005 . 